Georgina Ennis-Reynolds is a principal lecturer at the School of Planning, Oxford Brookes University, where she is also the course leader for the leisure planning undergraduate degree course. She is currently working on the ODPM's research report Assessing Need for Retail and Leisure Development.

Keywords:

sustainable development, need, leisure, planning, policy, multiplex
Georgina Ennis-Reynolds School of Planning Oxford Brookes University Headington Oxford $\mathrm{OX}_{3}$ oBP, UK Tel: +44 (o) 1865484142 Fax: +44 (o) 1865484081 E-mail: ghennis-reynolds@ brookes.ac.uk

\section{Sustainable development and multiplexes}

\section{Georgina Ennis-Reynolds}

Received: 27 May 2002

\begin{abstract}
The move of leisure development back into urban centres in the UK was precipitated by a change of planning policy based on the town centre as the preferred location for new development. The economic, social and environmental arguments behind the policy change broadly encompass the doctrine of sustainable development that underlies current land use planning policy. The UK government sees the town and country planning system as the main vehicle for implementing sustainable development principles.

The current framework of planning policy for commercial leisure could be described as piecemeal, essentially consisting of advice for planning authorities in parts of two Planning Policy Guidance notes. However, there are several key themes that represent strong policy direction to planners and developers. These are the requirement for development plans to identify sites for possible leisure development, the high profile of the sequential approach and, more recently, a focus on the demonstration of 'need' for development. All of these themes are consistent with achieving more sustainable patterns of leisure development.

This paper traces the evolution of planning policy for commercial leisure and discusses the contribution of multiplex development to sustainability, examining environmental, social and economic sustainability. The evaluation is supported by a survey of the opinions of leisure professionals on in-town cinema development and sustainability.
\end{abstract}

\section{INTRODUCTION}

Out-of-town locations are now seen as undesirable for leisure developments because they encourage private car use and longer journeys, use precious greenfield sites, lead to the decline of the urban centre by drawing people away from towns and are largely inaccessible by public transport. By contrast, it is felt that in-town development involving leisure uses can contribute greatly to the creation of an evening economy based around entertainment, drinking and eating out. Leisure development can also sustain the vitality and viability of the centre by attracting a wider range of people to facilities and encouraging further visits by fostering interest and familiarity. The greater access to urban centres afforded by public transport means leisure opportunities are available to more people. Finally, the sympathetic redevelopment of 
Table I: New multiplex cinemas by location type, 1995-2000

\begin{tabular}{rrrrrrrr}
\hline & \multicolumn{2}{c}{$\begin{array}{c}\text { Total sites } \\
\text { No. }\end{array}$} & No. & $\%$ & Out of centre & \multicolumn{2}{c}{ Out of town } \\
& & 2 & 40 & - & - & 3 & No. \\
\hline 1995 & 5 & 5 & 29 & 2 & 14 & 7 & 50 \\
1996 & 14 & 3 & 16 & 2 & 11 & 14 & 74 \\
1997 & 19 & 6 & 24 & 4 & 17 & 15 & 60 \\
1998 & 25 & 8 & 31 & 6 & 23 & 12 & 46 \\
1999 & 26 & 11 & 46 & 5 & 21 & 8 & 33 \\
2000 & 24 & & & & & & \\
\end{tabular}

urban areas through good architectural design of new buildings for leisure and other uses and the treatment of public spaces can counter perceptions about centres as unsafe and unclean.

The effectiveness of planning policy in encouraging development in the more favoured 'centre' or 'out-of-centre' sites compared to out-of-town locations can be shown with respect to multiplexes. Table $1^{1}$ shows that by the year 2000, two-thirds of new multiplex cinemas were opened in centre/out-of-centre locations compared to one-third out of town.

This demonstrates that, on the face of it, the implementation of planning policy is resulting in more sustainable development patterns with respect to multiplexes. However, the relationship between sustainability and planning policy for leisure needs to be examined in more detail in order to assess whether other objectives of sustainability are being achieved.

\section{SUSTAINABILITY IN PLANNING POLICY}

Sustainable development is most commonly defined as development "which meets the needs of the present without compromising the ability of future generations to meet their own needs. ${ }^{2}$ In the UK, the contribution of leisure to sustainable development was outlined in the first national strategy for sustainability, published by the Conservative government in 1994 . $^{3}$ It focused primarily on tourism and leisure in the 'natural' environment rather than urban-based leisure.

\section{Quality of life}

Its successor, A Better Quality of Life, was published in $1999^{4}$ and defined sustainable development as being 'about ensuring a better quality of life for everyone, now and for generations to come' (paragraph 1.1). It refers to the role that the statutory landuse planning system has in helping to create more sustainable communities through more sustainable patterns of development in urban areas. Planning policies should (paragraph 7.57) 'promote regeneration, social inclusion and more sustainable patterns of development. In particular, shopping, leisure and entertainment, offices and other key town centre uses should, wherever possible, be located within existing centres.'

It is felt that local government, as the level of governance closest 
Aims of sustainability to the people, is the most appropriate level at which to deliver sustainable development. This is because as well as its statutory planning function, it also has responsibility for environmental health and waste management. ${ }^{5}$ In addition, local government has duties in respect of leisure and tourism that are increasingly important to local economies.

The government's review of progress towards sustainable development, published in $2002,{ }^{6}$ continues to emphasise the economic (a sustainable economy), the social (building sustainable communities) and the environmental (managing the environment and resources) themes of sustainability as well as its global dimension. Naturally these themes are not mutually exclusive - for example, building sustainable communities involves addressing environmental degradation and local and regional economies as well as people's social needs for better health, housing and access to services and recreation. This necessarily integrated pursuit of sustainable development supports the view that the planning system is the main vehicle for its implementation.

Overall since 1987 sustainable development has been mainstreamed into public policy as a more mixed concept, stretching to encompass social and (more controversially) economic notions of sustainability as well as environmental resource use. Current policy for sustainability has four main aims:

- social progress which recognises the needs of everyone

- effective protection of the environment

- prudent use of natural resources

- maintenance of high and stable levels of economic growth and employment. $^{7}$

In practice many local authority development plans now contain a general policy for sustainable development. Depending on how urban or rural an authority is, the planning policy may be expressed in terms of a presumption against development that encourages unnecessary travel patterns and/or one that seeks to ensure the protection of the environment by reducing the need for the development of greenfield sites.

\section{THE EVOLUTION OF PLANNING POLICY FOR COMMERCIAL LEISURE}

Central government national advice for land-use planning policy is set out in a series of Planning Policy Guidance notes (PPGs). Local planning authorities have to take PPGs into account in their own development plans and in deciding particular development control decisions. PPG1 sets out the general approach to planning. It stresses the importance of focusing development in and around urban centres and outlines its key policy themes of sustainable development and its translation through the mixing of land uses and the improved design quality of new development. ${ }^{8}$ 


\section{Planning guidance for leisure}

\section{Commercial leisure and 'need'}

There is no PPG on leisure as a land use, although as PPG21 on tourism states, whether for leisure or tourism, '... for planning purposes it is the location, scale and environmental implications that matter rather than the particular type of user or the purpose of their visit' (paragraph 2.2). ${ }^{9}$ However, the lack of guidance for commercial leisure was noted in the review on the effectiveness of PPG17 on sport and recreation, which concluded inter alia that:

- there is a need to develop further guidance for the effective implementation of schemes for commercial leisure

- there is a need for further detailed investigation of the various forms of commercial leisure, how these should be treated in planning guidance and any other actions that should be taken. ${ }^{10}$

Overall, instead of explicit planning guidance on urban leisure development, several PPGs either mention leisure or cover issues that are relevant to leisure development.

The main PPG relating to commercial leisure development is revised PPG6 on retailing and town centres, ${ }^{11}$ which has two main policy priorities. First is a concern with maintaining an efficient, competitive and innovative retail (and presumably leisure) sector and the need to sustain and enhance the vitality and viability of centres, principally through a mix of land uses, including commercial leisure uses. Second is an attempt to focus investment and development in centres so a wider range of facilities are physically accessible by a choice of transport means. Both of these objectives can be said to promote sustainable development because of their economic and social implications.

PPG6 also encourages the relationship between commercial leisure and the evening economy, and states that the local planning authorities should work with the leisure industry to develop strategy and policies that support the evening economy. Arguably the missed opportunity for the commercial leisure industry to influence leisure planning policy is in the consultation over planning policy guidance and in the preparation of local authority development plans. ${ }^{12}$ PPG6 suggests that development plans should work with the private sector 'to assess need or market demand' (paragraph 1.7).

Much has been made of the justification for commercial leisure development in terms of need. ${ }^{13}$ The assessment of need with regard to commercial leisure facilities is problematic. While there is a history of assessing the provision for publicly provided leisure facilities such as swimming pools, libraries and open space, ${ }^{14}$ with commercial facilities need is more often used to mean physical capacity to accommodate a development or market demand based on expenditure. In his attempt through a parliamentary question to clarify the issue of need in February 1999, the Planning Minister Richard Caborn stated (somewhat unhelpfully) that while capacity and demand may form part of the demonstration of need, need 


\section{Leisure travel}

\section{Positive approaches to leisure}

may in fact be something other than this. ${ }^{15}$ This could be taken as a distinction between social need and market want, and imply that the regulation of the development of commercial leisure in some locations may in part be based on some kind of assessment of community 'felt need'. ${ }^{16}$ On the ground, developer pressure in some towns and cities has led directly to attempts by local authorities and developers themselves to assess the need for leisure development using a variety of methods. ${ }^{17}$

PPG13 on transport provides key guidance advice on how local authorities should integrate transport and land-use planning. ${ }^{18}$ In the section on the location of a development, the guidance states that leisure travel is the fastest area of traffic growth. However, while tourism and leisure journeys account for about one-quarter of all journeys, the number of leisure journeys per person per year has remained static. ${ }^{19}$ It is the distance or leisure miles that people are willing to travel which have increased. PPG13 stresses that local authorities' policies should ensure that new leisure attractions are readily accessible by a range of means of transport and 'where possible use sites in existing urban areas' (paragraph 3.11). In the section on leisure, the guidance states that the policies in the local plan should inter alia concentrate facilities in town centres and other locations well served by public transport. In this it supports the guidance in PPG6. However, it goes further in suggesting that local planning authorities should in their development plan "provide town centre locations for cinemas and theatres to give vitality in the evenings and maintain and encourage the provision of local leisure and entertainment facilities' (paragraph 3.12). This leads to another feature that is important to commercial leisure development, known as the plan-led approach, which characterises the development control process. The policies in the development plan are the first consideration in development control decision making. This means that if the planning process is to encourage and direct development into urban areas, positive and encouraging policies rather than restrictive policies for leisure are necessary. One positive planning approach is the identification of sites for development through the use of design briefs and the identification of parts of centres for specific uses such as leisure in the development plan itself. Another is planning policy that seeks to group leisure and related uses (such as A3 food and drink uses) together to create a leisure zone or quarter. In practice the recognition of the economic importance of leisure development by local authorities has led to a more serious consideration of commercial leisure as a land use in plan making.

Another feature of current planning policy with relevance for commercial leisure development is the sequential approach. This is an approach applied to site selection that requires potential developers to demonstrate that they have considered locations in the urban centre first, followed by edge-of-centre locations, before other sites. Out-of centre sites should only be considered if more central sites are not available and only if they are accessible by a 
range of means of transport. The sequential approach also emphasises assessment of need or market demand, and requires developers to be flexible on format, scale, design and car parking in order to fit into centres or to consider splitting schemes to fit sites that are more central. A Better Quality of Life (1999) makes the policy clear: 'Before development is allowed outside such [town] centres, developers must first demonstrate that there is no more central site and that there is unmet need for the development - the so-called sequential approach' (paragraph 7.57, emphasis added).

Analysis of the sequential approach with respect to retail development has revealed an inconsistency over the interpretation of the sequential approach. ${ }^{21}$ Developers and consultants are largely interpreting the approach as relating to the 'built form' of the development, which means that if a very large development is proposed it is unlikely that there will be any suitable town-centre or edge-of-centre sites in terms of physical size. The built form interpretation seems to overlook the guidance in PPG6 that developers be flexible about their trading formats. Local authorities and planning inspectors also use an interpretation based on 'class of goods', which relates to whether the goods to be sold from the proposed development could be successfully retailed from another more central site with a different built form. For commercial leisure development this could mean that different components of a proposed scheme are disaggregated and located on separate sites depending on type of leisure use. For example, for a health and fitness centre this could mean that the gym, café and bar are located in a more central position. They have a more flexible physical format than indoor racquet courts or a swimming pool, which could operate from an edge-of-town location in a more traditional leisure box format. While in theory this seems a sensible application of the sequential approach, for operators it creates problems when crosssubsidisation from more commercial to less commercial components is required to create a facility that is attractive enough to generate enough footfall to be financially sustainable.

In summary, while the current framework of planning policy for commercial leisure could be described as fragmented, there are several key themes that represent strong policy direction for planners and developers. The requirement for development plans to identify sites for possible leisure development, the high profile of the sequential approach and the demonstration of need are part of the evolution of planning policy for commercial leisure development which is outlined in Table $2 .^{22}$

The contribution of urban cinema development to sustainability is not an exact science. The following therefore represents a reasonable deduction of the plus and minus points of commercial in-town development compared to out of town. The discussion focuses on multiplexes and is supported by the results of a short questionnaire survey of leisure professionals $(\mathrm{n}=80)$ on new cinema development, sustainability and planning policy. 
Table 2: The evolution of planning policy for commercial leisure development ${ }^{22}$

\begin{tabular}{|c|c|}
\hline Late $1980 \mathrm{~s}$ & Laissez faire/reactive approach to planning, no policy for leisure projects - near free for all \\
\hline 1993 & PPG6 Town Centres and Retail Development ${ }^{23}-$ did not mention leisure specifically \\
\hline \multirow[t]{6}{*}{1994} & Change in approach: \\
\hline & $\begin{array}{l}\text { - concern about reducing the need to travel, particularly following recognition that leisure trips } \\
\text { showed the fastest increase in travel }\end{array}$ \\
\hline & $\begin{array}{l}\text { - importance of the development plan as the main consideration in proposals for development } \\
\text { and in appeals against refusal }\end{array}$ \\
\hline & - growing concern about impact on town centres of out-of-town retail and leisure development \\
\hline & $\begin{array}{l}\text { PPG13 Transport }{ }^{24}-\text { specifically mentions leisure in terms of location in centres and } \\
\text { opportunities for access by different means of transport }\end{array}$ \\
\hline & $\begin{array}{l}\text { Environment Committee inquiry Shopping Centres and their Future }{ }^{25} \text { recommended revision of } \\
\text { policy against out-of-town development }\end{array}$ \\
\hline 1996 & $\begin{array}{l}\text { PPG }{ }^{26} \text { revised after consultation with leisure industry; introduces the sequential approach for } \\
\text { preferred locations and emphasises the plan-led approach; section on leisure and the evening } \\
\text { economy }\end{array}$ \\
\hline \multirow[t]{4}{*}{1997} & $\begin{array}{l}\text { Secretary of State refuses permission for a ten-screen out-of-town multiplex at Eastleigh on the } \\
\text { grounds of failure of the sequential test }\end{array}$ \\
\hline & $\begin{array}{l}\text { Hampshire County Council produces Supplementary Planning Guidance: Major Commercial Leisure } \\
\text { Uses }{ }^{27} \text { to help deal with development pressure across the area from leisure operators/ } \\
\text { developers }\end{array}$ \\
\hline & $\begin{array}{l}\text { Norwich City Council publishes its Multiplex Cinema Methodology }{ }^{28} \text { which was carried out to } \\
\text { assess the relative merits of five competing proposals for cinemas in the city }\end{array}$ \\
\hline & Both of these publications seen as good practice by the DETR \\
\hline 1999 & $\begin{array}{l}\text { The Planning Minister places an emphasis for planning decisions to take into account the 'need' } \\
\text { for development (specified in PPG6); this is to apply especially to development outside the } \\
\text { centre; the sequential test is also stressed; methods including measurement of capacity and } \\
\text { demand can be used to measure 'need' }\end{array}$ \\
\hline 2000 & More new multiplexes open in central locations compared to out of town \\
\hline \multirow[t]{3}{*}{2001} & Development slows down; closure of first multiplexes \\
\hline & $\begin{array}{l}\text { DETR revises PPG13 on Transport }{ }^{29} \text { which encourages mixed-use development around } \\
\text { transport sites }\end{array}$ \\
\hline & $\begin{array}{l}\text { DETR publishes Research Report into Planning for Leisure and Tourism }{ }^{30} \text { which recognises their } \\
\text { contribution to GDP, the issue of leisure/tourism trips, and the environmental and social impacts } \\
\text { caused by leisure/tourism development, including on urban centres }\end{array}$ \\
\hline \multirow[t]{3}{*}{2002} & $\begin{array}{l}\text { Green paper on the planning system published; }{ }^{3 i} \text { Use Class Order including leisure uses to be } \\
\text { reviewed }\end{array}$ \\
\hline & ODPM publishes review on the effectiveness of PPG6 (forthcoming) \\
\hline & $\begin{array}{l}\text { ODPM publishes report on Assessing Need and Impact of New Retail and Leisure Development } \\
\text { (forthcoming) }\end{array}$ \\
\hline
\end{tabular}

\section{ECONOMIC SUSTAINABILITY: A SUSTAINABLE ECONOMY}

The role of leisure development in creating and supporting an evening economy, supporting town-centre functions and stimulating regeneration is well recognised. ${ }^{32}$ However, the commercial leisure industry as a whole is characterised by minimum wages and parttime employment. Given the size of their footprint, cinemas do not employ people in great numbers and the contribution of in-town multiplexes to employment opportunities for the local population is therefore relatively minimal.

As an industry, cinema exhibition has traditionally been short

\section{The exhibition industry} termist. Even in its heyday in the mid-1940s, when admissions reached 1,635 million annually, ${ }^{33}$ there was very little reinvestment and refurbishment of theatres, which meant by the 1950s they were in no position to compete with the new technology and comparative home comfort of television. Lack of maintenance turned many local cinemas into the so-called 'fleapits', and the long decline of cinema going continued until the mid-1980s. This contrasts sharply with the constant updating of leisure formats and commitment to new technologies prevalent in the leisure sector currently. The exhibition 


\section{Cinema competition - cannibalisation}

industry is no longer fatalist about new forms of media, having battled against television and video. However, the industry does have to compete heavily for the limited leisure time people have available. ${ }^{34}$ In order to encourage people to go to their cinemas, operators have marketed their 'offer', stressing the branding of their multiplexes and an array of premium services (such as automated ticket booking and seating systems, special luxury seating and menus). All of this seeks to accentuate the total experience of cinema going rather than a specific film itself.

In terms of economic viability, it is much more costly to build in town. However, apart from the initial development outlay, the key issue for operators/developers is existing or proposed competition, either with other cinemas or other leisure uses. The profit margins for operators are now very slim and rely heavily on the associated secondary spend rather than box-office revenue (which is generally spoken for by film rental). If competition dilutes financial viability - with audiences defecting to other cinemas or eating and drinking elsewhere, then not all operators can survive. At present, with the market reaching saturation and over-supply of screens in some areas, the extreme competition between cinemas over audience admissions has become known as cannibalisation. This has occurred principally where new multiplexes have out-competed traditional high-street cinemas, resulting in their closure. Arguably the move of the multiplexes into town may have accelerated the closure of the traditional cinemas, leaving customers with only the more expensive admission prices of the multiplex.

The recent slowdown in cinema admissions compared to the increase in the number of new screens has led to questions about the long-term financial viability of the exhibition industry. While the economic sustainability of the cinema industry is ultimately dependent on the continuing supply of popular films, the in-town multiplex is arguably at greater risk when compared to out of town because of the:

- greater investment involved in redeveloping constrained in-town sites compared to the single-level leisure box format on greenfield out-of-town sites

- higher costs associated with the much higher design and fit-out specification demanded by urban locations

- competition with other in-town leisure and retail uses for leisure expenditure compared with out of town, where the multiplex is usually the anchor attraction

- need to recoup the greater costs quickly before obsolescence requires refurbishment; the large investment in development and the high rental values that result mean that any future use must also be of a high value ${ }^{35}$

- limited potential for obvious alternative use of cinemas with stadium seating compared to the warehouse layout of out-oftown multiplexes ${ }^{36}$ 
- generally fewer numbers of screens in new in-town multiplexes compared to out of town, leading to reduced financial viability for operators.

Generally the in-town development process for new multiplexes is characterised by very conflicting objectives between cinema developers/operators and local (planning) authorities. Local authorities often see cinemas as a desirable 'cultural' amenity, at the top of the wish-list of leisure needs for a community and essential in the urban centre to create vitality through evening footfall. For the exhibition industry, the greater complication and expense involved in developing in town is also fraught with uncertainty over whether other cinema development will be granted permission in the future and affect financial sustainability. ${ }^{37}$

\section{SOCIAL SUSTAINABILITY: BUILDING SUSTAINABLE COMMUNITIES}

Dodona reviewed the contribution of different locations of cinemas to planning policy goals of transport, vitality, regeneration and inclusion and demonstrated that only central locations fulfil all the policy objectives. This is shown in Table $3{ }^{38}$

In reality, in terms of being socially inclusive there has simply not been enough of the right kind of information gathering to support the assumption that in-town cinemas are more socially inclusive. Cinema attendance is a young persons' activity, and while in-town cinemas may be more physically accessible through a range of means of transport including public transport, if the higher development and running costs are passed on in higher ticket prices $^{39}$ then they may be economically exclusive. As mentioned earlier the change in planning policy that precipitated the direct head-to-head competition between traditional high-street cinemas and multiplexes locating in town usually results in the multiplex cannibalising the traditional cinema. While the majority of the audience will be prepared to pay the higher prices of the multiplex for the luxury cinema-going experience, some will not be able to.

\section{Social inclusion} There is some evidence that women and family groups prefer the out-of-town multiplex experience because of its ease of parking and perceived greater safety. ${ }^{40}$ This suggests that out-of-town locations have resulted in greater attendance by non-traditional cinemagoers. If this is the case then the move into town may well discourage this inclusiveness. However, the multiplex phenomenon is sustained by

Table 3: How do these types of locations contribute to policy goals?

\begin{tabular}{lllll}
\hline $\begin{array}{l}\text { Policy goal } \\
\text { Location }\end{array}$ & Transport & Vitality & Regeneration & Inclusion \\
\hline Centre & Yes & Yes & Yes & Yes \\
Out of centre & Yes & No & Yes & Yes \\
Out of town & No & No & No & No \\
\hline
\end{tabular}




\section{Combined leisure trips}

American 'blockbuster' films aimed at young people, who provide the greatest secondary spend and are the target audience for cinema advertisers. While in-town locations may make cinemas more convenient to visit, unless the film product (the 'offer') or film programming is changed to screen films that appeal to a wider range of audiences, then it is difficult to see how mainstream cinema going can ever be truly socially inclusive.

The move of leisure development back into the city centre to support the evening economy and foster the so-called '24-hour city' may ironically have reduced opportunities for women, families and older people. The grouping of leisure uses, including multiplexes, within urban centres to form leisure quarters tends to create a synergy that appeals exclusively to young people. Furthermore, the concentration of themed public houses, bars and fastfood outlets tends to encourage leisure 'grazing', predominantly by young groups of males. The reanimation of the city centre at night to widen leisure opportunities for all may be having the opposite effect.

On average new multiplexes in urban centres have fewer screens than their out-of-town counterparts. Operators claim that multiplexes with more screens allow for greater flexibility in programming. In effect popular films then subsidise the screening of niche and specialised films. Arguably the planning constraints that have resulted in the smaller multiplexes in town have reduced inclusiveness because of the diminished choice of film offer.

Finally the familiar single-level format of the out-of-town multiplex with dedicated parking on the doorstep and at the same level is much more accessible for wheelchair and disabled customers than its multistorey in-town counterpart.

\section{ENVIRONMENTAL SUSTAINABILITY: MANAGING THE ENVIRONMENT AND RESOURCES}

One of the arguments put forward by developers locating together to create large leisure parks in out-of-town locations was the supposed synergy between the different leisure elements or between the different uses in a mixed scheme. Large leisure or mixed-use developments with their associated enabling development such as parking provision could therefore be justified through economic sustainability grounds. It could then be suggested that dual-purpose visits to large-scale leisure parks meant a net saving in leisure trips and an overall contribution to environmental sustainability.

However, research has failed to find any evidence of strong synergy between leisure uses on large-scale leisure schemes, apart from a combination with catering. ${ }^{41}$ The conclusion is therefore that 'town centres are equally, if not better placed, to provide for these synergies without conflicting with the principles of sustainable development' (paragraph 12.18). ${ }^{42}$ The contribution to environmental sustainability of the reduced leisure traffic impact by focusing leisure development in urban centres is presumed rather than conclusive. 


\section{Leisure-led regeneration}

\section{Reuse of cinemas limited}

The paucity of architectural quality in (at least the earlier out-oftown) multiplexes has been recognised by Gray, who describes '... the industrial shed with the Lego land appendages that is the average multiplex'. ${ }^{43}$ One of the major impacts of planning policy in coercing leisure development back into central locations has been on the quality of the architecture and design of the newer cinema developments.

In terms of regeneration of an area, there are many examples of so-called leisure-led renaissance in major cities. ${ }^{44}$ Typically urban renewal on such a scale involves a combination of flagship cultural development, associated mixed-use leisure and retail development (including a multiplex and associated restaurants, cafés and bars), investment in transport infrastructure and improvements to public space and the urban environment generally. However, leisure-led regeneration has also been occurring on a more modest scale in many smaller cities and towns. Many development plans have policies supporting the creation of leisure 'quarters' or zones within urban centres, where leisure and entertainment land uses are grouped together to create synergy and attract footfall to develop an evening economy.

As in out-of-town locations such as leisure parks, the multiplex has been the anchor development of in-town regeneration, seen as the essential element to draw in customers and support complementary land uses. The explosion of multiplex development has fuelled a confidence in cinema development which has meant that planning issues, such as reuse of multiplex buildings should the cinema exhibition industry falter, were not raised as part of the development process. Most leisure parks have planning conditions as part of their permission which preclude significant changes to the mix of uses and often resist the loss of the cinema element of the development. The Use Classes Order (UCO) which requires that planning permission be sought for changes between certain uses, such as between leisure and retail, also restricts the potential reuse of sites. ${ }^{45}$

However, the slowdown in the multiplex market has led to a situation of déjà $v u$, with the possibility of cinemas becoming redundant again as they did in the long decline that coincided with the rise of television. Very few of the 5,500 cinemas which operated at cinema's peak in the mid-1940s exist today either as cinemas or other uses. English Heritage has documented the rather limited range of successful alternative uses for redundant listed cinemas. ${ }^{46}$ The main reason behind this is the high specificity of cinema buildings, which are very much designed for their purpose. In-town cinemas are highly particular to their site, designed to fit in with surroundings or as part of a larger development, for example a shopping centre. Out-of-town multiplexes on the other hand are more homogeneous, with a single-level leisure box format and extensive car-parking provision permitted because of the lack of land constraints. Changes to the basic structure of a multiplex 
Economic vitality and viability building are expensive given the stadium seating built into concrete and steel supported structures. ${ }^{47}$ Changing use from a modern cinema is therefore difficult and expensive demolition is likely to give a greater chance of successful redevelopment, particularly for an in-town cinema. The manipulation of the original multiplex format may have led to an architectural/aesthetic improvement to the urban environment and therefore a contribution to sustainable development, but it may be at the expense of flexibility in terms of reuse of the building in the future. If this is the case then in terms of environmental sustainability it is likely that the out-of-town cowshed cinema designs prove much more physically and financially adaptable than their highly designed in-town counterparts.

\section{CONCLUSIONS}

One of the main justifications behind the change in planning policy was a reduction in the traffic generated by out-of-town development. It follows that a significant contribution to sustainability of in-town leisure development, including the multiplex, is the environmental benefits resulting from the greater use of public transport and a reduction in private car use for leisure trips. There is also a related social equity debate which reasons that leisure opportunities located in urban centres are more accessible to a wider range of people. This argument would seem to relate to the current definition of sustainable development concerning improvements to the quality of life. However, the most compelling justification for the change in planning policy lies in the contribution that in-town leisure development and leisure-related expenditure can make to sustaining the economy through the expansion of trade into the evening. The main thrust of the policy change was not on environmental or social grounds but on the need to protect the economic vitality and viability of urban centres. This is supported in Table 4, which contains some of the results from a survey of leisure professionals. For the research respondents were asked to express their opinion on the importance of in-town

Table 4: The contribution of in-town multiplexes to sustainable development

\begin{tabular}{lll}
\hline Sustainability aim & Contribution & $\begin{array}{l}\text { Survey mean } \\
\text { ('importance') }\end{array}$ \\
\hline A sustainable economy & & 4.42 \\
& - creating and supporting the evening economy & 4.08 \\
& - stimulating regeneration & 4.03 \\
Building sustainable communities & - supporting key town centre functions & 3.68 \\
& - greating employment opportunities & 4.17 \\
Managing the environment and & - improved quality of life & 4.00 \\
resources & - safety concerns if parking not on site or adjacent & 3.42 \\
& - encourages use of public transport & 3.82 \\
& - reuse brownfield/protect greenfield sites & 3.79 \\
& - reduces need to travel through combined trips & 3.50 \\
& - improved urban design of an area & 3.34
\end{tabular}


multiplexes to a set of sustainability factors, on a scale of $5=$ very important, $3=$ neither important nor unimportant and $1=$ very unimportant. The higher the mean score the more important the factor in relation to in-town multiplexes.

The survey suggests that leisure professionals concur on the relative importance of multiplexes to economic sustainability compared to environmental and social sustainability aims. Elsewhere in the survey there was less agreement between the professions on whether the move into town has compromised the reasons why multiplexes have been so successful. However, operators, developers, planners, consultants and others generally agree that in-town multiplexes are less adaptable to other uses than out-of-town ones. This should be borne in mind by the policy makers in case changes in the fast-moving leisure sector mean urban areas become burdened with obsolete cinema buildings once again.

\section{References}

1. Dodona Research (2001) 'New cinema development - Where are they now?', paper given at the 2001 Cinemas in the Community Conference, 3rd May, London.

2. World Commission on Environment and Development (1987) Our Common Future, Oxford University Press, Oxford.

3. Department of Environment (1994) Sustainable Development - The UK Strategy, Cm 2426, HMSO, London.

4. Department of Environment, Transport and the Regions (1999) A Better Quality of Life - A Strategy for Sustainable Development, Cm 4345, DETR, London.

5. Cartwright, L. (1997) 'The implementation of sustainable development by local authorities in the south east of England', Planning Practice and Research, Vol. 12, No. 4, pp. 337-347.

6. Department of Environment, Food and Rural Affairs (2002) Achieving a Better Quality of Life - Review of Progress Towards Sustainable Development, DEFRA, London.

7. Department of Environment, Transport and the Regions, ref. 4 above.

8. Department of Environment (1997) General Policy and Principles, Planning Policy Guidance PPG1, HMSO, London.

9. Department of Environment (1992) Tourism, Planning Policy Guidance PPG21, HMSO, London.

10. Department of Environment, Transport and the Regions (1998) The Effectiveness of Planning Policy Guidance on Sport and Recreation, DETR, London.

11. Department of Environment (1996) Town Centres and Retail Developments, Planning Policy Guidance Revised PPG6, HMSO, London.

12. In reality the long time scales involved in policy and plan making mean that few fastmoving private sector organisations participate in the strategic elements of the planning process. While the leisure industry was involved in the revision of PPG6, the lobby group Business in Sport and Leisure usually represents the interests of the commercial leisure industry.

13. See, for example, Department of Environment, Transport and the Regions (2001) The Research Report on Planning for Leisure and Tourism, www.planning.detr.gov.uk/ rropflat; Butter, I. (2001) 'Planning ahead! Understanding the government's future leisure planning policy', Journal of Leisure Property, Vol. 1, No. 4, pp. 337-349; Adlard, H. (2000) 'The "need" for retail development', Journal of Planning Law, May, pp. 522534; Chase, G. and Morrissey, J. (1999) The 'Need' for Development, Retail Development and Property Briefing Paper 8, www.chaseandpartners.co.uk.

14. See, for example, the methodologies used for assessing need/demand for a variety of sport and leisure facilities in Chapter 7 of Torkildsen, G. (1999) Leisure and Recreation Management, E. and F. N. Spon, London. 
15. Caborn, R. (1999) Planning Applications for Shopping and Leisure Schemes Should be Assessed on the Basis of Need, answer to a parliamentary question from Alan Johnson MP, 11th February, www.nds.coi.gov.uk.

16. For a discussion on need in a leisure context see Mercer, D. (1973) 'The concept of recreational need', Journal of Leisure Research, No. 5, Winter, pp. 37-50.

17. Office of the Deputy Prime Minister (forthcoming) Assessing Need and Impact of New Retail and Leisure Development, ODPM, London

18. Department of Environment, Department of Transport (1994) Transport, Planning Policy Guidance PPG13, HMSO, London.

19. Department of Transport, Local Government and the Regions/National Travel Survey Unit (2001) Focus on Personal Travel, TSO, London, www.transtat.dtlr.gov.uk/personal.

20. DETR (1999) ref. 4 above.

21. CB Hillier Parker (2000) The Sequential Approach to Retail Development, report of a national research project for the National Retail Planning Forum, British Council of Shopping Centres, Department of the Environment, Transport and the Regions, www.nrpf.org/publications.htm.

22. Developed from Bach, M. (1999) 'Planning for leisure: A positive approach', paper given at the 1999 Cinemas in the Community Conference, 4th March, London.

23. Department of Environment/Welsh Office (1993) Town Centres and Retail Developments, Planning Policy Guidance 6, HMSO, London.

24. Department of Environment, Department of Transport, ref. 18 above.

25. Environment Committee (1994) Shopping Centres and their Future, House of Commons, Environment Committee Report Session 1993-94, HMSO, London.

26. Department of Environment, ref. 11 above.

27. Hampshire County Council (1997) Supplementary Planning Guidance: Major Commercial Leisure Uses, Hamshire County Council.

28. Norwich City Council (1997) Multiplex Cinema Methodology, Norwich City Council, Norwich.

29. Department of Environment, Transport and the Regions (2001) Transport, DETR, London.

30. DETR, ref. 13 above.

31. House of Commons, Department of Transport, Local Government and the Regions (2002) Planning Green Paper, Thirteenth Report of Session 2001-02, The Stationery Office, London

32. For example, see Comedia (1991) Out of Hours: A Study of the Economic and Social Life of Town Centres, Gulbenkian Foundation, London; the collection of papers in Montgomery et al. (1995) 'Urban vitality and the culture of cities', Planning, Practice and Research, Vol. 10, No. 2, pp. 101-255. In the research survey the question concerning the contribution of in-town multiplex schemes to creating/supporting an evening economy received the highest mean response of 4.42 or important/very important.

33. Screen Digest/Screen Finance/BFI (2002) UK cinema admissions 1933-2001, www.bfi.org.uk/facts/stats/alltime/uk-admissions.html.

34. See, for example, the Henley Centre COMMET research which shows that the total time spent on media per week has remained constant at around 60 hours a week since 1989. However, during the same period there has been a massive increase in leisure media output such as television channels, Web pages, magazines and music releases, computer software and cinema screens.

35. Peters, R. (2002) Redundant Multiplexes, paper presented to Fifth Annual Cinemas in the Community Conference, London, Landor Conferences.

36. This argument ignores any constraints on future use due to planning conditions as part of the original permission, lack of flexibility to change the leisure land use because of the Use Class Order or restrictive covenants forbidding use as cinemas by subsequent owners, usually to prevent competition.

37. This was raised as a significant issue by Richard Segal, chief executive of Odeon Cinemas, during a question and answer session at the 2002 Fifth Annual Cinemas in the Community Conference.

38. Dodona Research, ref. 1 above.

39. Dodona Research (2000) Cinemagoing 8, Dodona Research, Leicester, sets out the 
business rationale for the higher ticket prices of multiplexes compared to traditional cinemas.

40. For example, Robinson, S. (1996) Multiplexes and Planning Policy, a CB Hillier Parker presentation, states that in multiplexes 60 per cent of the audiences are women, compared to only 38 per cent in traditional cinemas.

41. See paragraphs 12.16-12.18 in Department of the Environment, Transport and the Regions, ref. 13 above.

42. DETR (2001) Research Report on Planning for Leisure and Tourism, www.planning.detr.gov.uk/rropflat.

43. Gray, R. (1996) Cinemas in Britain - One Hundred Years of Cinema Architecture, Lund Humphries and Cinema Theatre Association, London.

44. For example, industrialised cities such as Manchester, Birmingham and Sheffield have sought to reinvent themselves through flagship sporting, cultural and arts-related development using lottery and other public sector funding as the catalyst for creating the confidence for further private sector investment.

45. For an analysis of the UCO and leisure development see Leisure Property Forum with Kingston University, Denton Wilde Sapte and King Stuge (2001) Leisure Property and the Use Classes Order: Are They Still Appropriate?, www.leisureprop.com.

46. English Heritage (1999) Picture Palaces - New Life for Old Cinemas, English Heritage, London.

47. Peters, ref. 35 above. 